\title{
Dose-Kinetics of Pancreatic Glucagon Responses to Arginine and Glucose in Subjects with Normal and Impaired Pancreatic B Cell Function
}

\author{
R. Assan ${ }^{1}$, S. Efendic ${ }^{2}$, R. Luft ${ }^{2}$ and E. Cerasi ${ }^{3}$ \\ ${ }^{1}$ Diabetes Department, Bichat Hospital, Paris, France, ${ }^{2}$ Department of Endocrinology, Karolinska Hospital, Stockholm, Sweden, and \\ ${ }^{3}$ Department of Endocrinology and Metabolism, Hadassah University Hospital, Jerusalem, Israel
}

Summary. Pancreatic glucagon responses to different amounts of intravenous arginine and glucose were studied in 10 insulin-dependent diabetics, 14 healthy controls (high insulin responders) and 15 subjects with decreased insulin response to glucose but normal intravenous glucose tolerance (low insulin responders). The dose-kinetics of the glucagon response was studied by using four different arginine doses. The suppressive effect of glucose was evaluated by infusing three glucose doses during a submaximal stimulation with arginine. The diabetics were tested first when under fair metabolic control and then following intensive treatment with insulin to produce near-normalisation of blood glucose. Finally, five subjects underwent insulin-induced hypoglycaemia. The changes in plasma glucagon and blood $\alpha$-amino-nitrogen in response to the four arginine doses were significantly correlated in all groups but the slope of the dose response curve was steeper in the poorly controlled-diabetics than in the non-diabetics. These diabetics displayed higher fasting plasma glucagon values than healthy controls (high insulin responders) (224 \pm 4 versus $151 \pm 22 \mathrm{pg} / \mathrm{ml}, p<0.01$ ), higher plasma glucagon responses to arginine and an absence of inhibition by glucose of the argininestimulated glucagon release. In strictly controlled diabetic patients, fasting plasma glucagon levels $(176 \pm 16 \mathrm{pg} / \mathrm{ml})$ were not significantly different from healthy controls, the glucagon response to arginine returned to the normal range, A cell suppressibility by glucose was restored and A cell stimulation by hypoglycaemia reappeared. In the low insulin responders, fasting plasma glucagon was not different from that of high responders $(107 \pm 12 \mathrm{pg} / \mathrm{ml})$, the slope of the dose response curve to arginine was similar in both groups and the A cells were inhibited by glucose to a similar extent. These results support the concept that islet A cell dysfunction in diabetes is not a primary phenomenon.
Key words: Glucagon, A cell, low insulin responders, diabetes.

The cause of the islet A cell abnormalities and their importance in the pathophysiology of diabetes mellitus remains controversial [1-5]. It has been suggested that A cell dysfunction, which is a secondary phenomenon in experimental diabetes, might be a primary defect in human diabetes [1]. If this hypothesis is correct, A cell dysfunction might be present in potentially diabetic subjects before the establishment of overt metabolic disturbances. On the contrary if hyperglucagonaemia is induced by the metabolic changes of diabetes, A cell function should be normal in overt diabetics in whom strict control of their disease is achieved. This has recently been demonstrated in some groups of aggressively treated patients [5-8].

In the present study islet A cell function has been evaluated using various doses of arginine and glucose in the following groups of patients. First, low insulin responders with a normal glucose disappearance but decreased insulin response to glucose infusion who have previously been demonstrated to have a higher probability of developing diabetes $[9,10]$. Second, insulin dependent diabetics before and after strict glycaemic control and third, normal healthy subjects.

\section{Subjects and Methods}

\section{Subjects}

The characteristics of the subjects are shown in Table 1. Sex distribution, age range and percentage ideal body weight were similar in all groups. No subject was obese. The non-diabetic subjects were classified as high or low insulin responders before the present study according to their insulin response to glucose infusion $[9,10]$. The $\mathrm{K}$ value of the IV glucose tolerance test was above 1.0 in all subjects. 
Table 1. Characteristics of the subjects studied

\begin{tabular}{lllll}
\hline Group & $\begin{array}{l}\text { Age } \\
\text { (years) }\end{array}$ & $\begin{array}{l}\text { Ideal body } \\
\text { weight }(\%)\end{array}$ & $\begin{array}{l}\mathrm{K} \text { value } \\
(\% / \text { min) }\end{array}$ & $\begin{array}{l}\text { Duration of } \\
\text { diabetes } \\
\text { (years) }\end{array}$ \\
\hline $\begin{array}{l}\text { High insulin } \\
\text { responders } \\
(n=14)\end{array}$ & $32 \pm 2$ & $92 \pm 3$ & $2.7 \pm 0.2$ & - \\
$\begin{array}{l}\text { Low insulin } \\
\text { responders } \\
(n=15)\end{array}$ & $37 \pm 2$ & $102 \pm 1$ & $1.6 \pm 0.1^{\mathrm{a}}$ & - \\
$\begin{array}{l}n \text { Diabetics } \\
(n=10)\end{array}$ & $28 \pm 3$ & $101 \pm 2$ & - & $10 \pm 2$ \\
\hline
\end{tabular}

Results are presented as mean \pm SEM. ${ }^{\text {a }}$ statistical significance of differences with the high insulin responders: $p<0.01$. Numbers of subjects are indicated in parentheses. $\%$ ideal body weight was calculated according to Statist Bull Metrop Life Insur Co [1959]

However, the low insulin responders presented significantly lower $\mathrm{K}$ values than the high responders as has previously been demonstrated in a larger group of subjects: $1.6 \pm 0.1$ versus $2.7 \pm 0.2 \% / \mathrm{min}$ [10].

All diabetic patients had been ketotic on admission and were insulin-dependent. Renal and hepatic function was normal as assessed by serum creatinine and alkaline phosphatase concentrations. No subjects were taking any medication other than insulin at the time of study. None had other chronic disease. The patients were tested first while on a single dose of Lente insulin (25-40 U), providing fair control of glycaemia. The blood glucose was $8.2 \pm 1.3 \mathrm{mmol} / \mathrm{l}$ fasting and $13.7 \pm 1.3 \mathrm{mmol} / 12 \mathrm{~h}$ after lunch. A second test was performed after one week of rigid control with Isophane insulin (20-34 $\mathrm{U}$ at $08.00 \mathrm{~h}$ and $10-34 \mathrm{U}$ at $20.00 \mathrm{~h}$ ). The blood glucose was $4.3 \pm 0.6 \mathrm{mmol} / 1$ fasting and $6.9 \pm 1.3 \mathrm{mmol} / \mathrm{l}$ $2 \mathrm{~h}$ after lunch (values collected on seven different days). In addition a slow IV infusion of insulin (Actrapid $1.7 \mathrm{U} / \mathrm{h}$ ) was maintained for the $12 \mathrm{~h}$ preceding and during the test in order to maintain blood glucose levels close to normal values.

\section{Investigations}

All tests were performed with the informed consent of the subjects and in accordance with the principles of the Declaration of Helsinki.

Arginine $\mathrm{HCl}$ (Vitrum, Stockholm, Sweden) was administered IV as a rapid injection followed by a constant rate infusion for $30 \mathrm{~min}$. Four doses were used: 1) $0.12 \mathrm{mmol} / \mathrm{kg}$ body weight as a bolus, followed by an infusion of $0.01 \mathrm{mmol} \cdot \mathrm{kg}^{-1} \cdot \mathrm{min}^{-1} ; 2$ ) $0.24 \mathrm{mmol} / \mathrm{kg}$ bolus and $0.02 \mathrm{mmol} \cdot \mathrm{kg}^{-1} \cdot \mathrm{min}^{-1}$ infusion; 3) $0.72 \mathrm{mmol} / \mathrm{kg}$ bolus and $0.04 \mathrm{mmol} \cdot \mathrm{kg}^{-1} \cdot \mathrm{min}^{-1}$ infusion; 4) $1.08 \mathrm{mmol} / \mathrm{kg}$ bolus and $0.07 \mathrm{mmol} \cdot \mathrm{kg}^{-1} \cdot \mathrm{min}^{-1}$ infusion. These tests are referred to below as arginine I, II, III and IV respectively.

Pancreatic A cell inhibition was studied by combining glucose administration with arginine III. The following glucose doses were used: $0.55 \mathrm{mmol} \cdot \mathrm{kg}^{-1} \cdot \mathrm{min}^{-1}$ for $30 \mathrm{~min} ; 1.38 \mathrm{mmol} / \mathrm{kg}$ bolus and $0.05 \mathrm{mmol} \cdot \mathrm{kg}^{-1} \cdot \mathrm{min}^{-1} ; 2.75 \mathrm{mmol} / \mathrm{kg}$ bolus and $0.11 \mathrm{mmol} \cdot \mathrm{kg}^{-1} \cdot \mathrm{min}^{-1}$. These are designated as glucose I, II, and III, respectively.

The four arginine doses were tested in 14 high insulin responders, 10 low insulin responders and 10 diabetics. The glucose + arginine tests were performed in five of the high responders and five of the low responders. In the 10 diabetics, A cell stimulation by arginine III and inhibition by glucose III were performed before and during optimised control. Finally, five of these diabetics underwent insulin-induced hypoglycaemia, obtained by IV infusion of $20 \mathrm{U}$ Actrapid over $30 \mathrm{~min}$.

All tests were performed in the supine position at $8.00-10.00 \mathrm{~h}$ after an overnight fast. At least one week elapsed between consecutive investigations. Venous blood samples were collected into chilled heparinised tubes, handled appropriately for further assays (see below) and then centrifuged at $+4^{\circ} \mathrm{C}$. The supernatants were stored at $-20^{\circ} \mathrm{C}$ until processing. Glucose was measured in whole blood by a glucose oxidase method [11]; $\alpha$-amino-nitrogen ( $\alpha$ $\mathrm{NH}_{2}$ ) by the cuprizone method [12] after deproteinisation with $5 \%$ $(\mathrm{w} / \mathrm{v})$ trichloracetic acid $(0.5 \mathrm{ml}$ for $0.1 \mathrm{ml}$ blood $)$. Alanine was determined by an enzymatic fluorimetric method [13] after deproteinisation of $0.5 \mathrm{ml}$ blood with $0.5 \mathrm{ml} 7.5 \%$ (w/v perchloric acid). Aprotinin (2,000 U/l ml blood) was added to the samples intended for hormone assay. Plasma immunoreactive glucagon (IRG) and insulin were determined by radioimmunoassay, using antiserum 30 K for glucagon (Professor R. H. Unger, Dallas, Texas) without prior extraction of plasma samples [14].

The lowest amount of glucagon standard which gave a significant variation from the zero standard of the bound/free ratio was $7 \mathrm{pg} / \mathrm{ml}$, corresponding in whole plasma to a lowest detectable value of $21 \mathrm{pg} / \mathrm{ml}$. Interassay variation was less than $5 \%$.

Results are presented as mean \pm SEM for each time point. The sum of the glucagon values during individual experiments was calculated to give the integrated glucagon response for $90 \mathrm{~min}$. Similarly the sum of the substrate variations from basal values was calculated in each individual experiment to give the net increase or decrease of blood glucose, $\alpha-\mathrm{NH}_{2}$ and alanine.

Standard statistical methods were used for analysis of results. Non-parametric statistics were used for comparisons of the summed (integrated) responses and of the sums of variations from basal values [15].

\section{Results}

\section{Basal Values}

Basal values were calculated for each subject by taking the mean of individual measurements on five to eight different occasions. In non-diabetic subjects there was no significant difference between high and low insulin responders with respect to fasting blood glucose levels $(4.2 \pm 0.1$ versus $4.3 \pm 0.1 \mathrm{mmol} / \mathrm{l})$ $\alpha-\mathrm{NH}_{2}(5.3 \pm 0.2$ versus $5.9 \pm 0.2 \mathrm{mmol} / \mathrm{l})$; alanine $(359 \pm 29$ versus $361 \pm 40 \mathrm{mmol} / \mathrm{l})$ and insulin $(24.0 \pm 0.7$ versus $24.0 \pm 1.4 \mathrm{mU} / 1)$. Plasma immunoreactive glucagon (IRG) levels were not significantly different between low insulin responders and the high responders $(107 \pm 12$ versus $151 \pm 22 \mathrm{pg} / \mathrm{ml})$. The diabetic patients differed significantly from the two other groups for fasting blood glucose $(9.2 \pm 0.3 \mathrm{mmol} / 1) ; \alpha-\mathrm{NH}_{2}(4.8 \pm 0.2 \mathrm{mmol} / 1)$ and plasma IRG $(224 \pm 4 \mathrm{pg} / \mathrm{ml})$. During the excellent control of the diabetics the differences for glucose $(4.3 \pm 0.02 \mathrm{mmol} / \mathrm{l})$ and IRG $(176 \pm 16 \mathrm{pg} / \mathrm{ml})$ disappeared, but not for $\alpha-\mathrm{NH}_{2}(4.7 \pm 0.2 \mathrm{mmol} / \mathrm{l})$. Blood alanine was not different from the other groups $(362 \pm 18 \mu \mathrm{mol} / 1)$. 

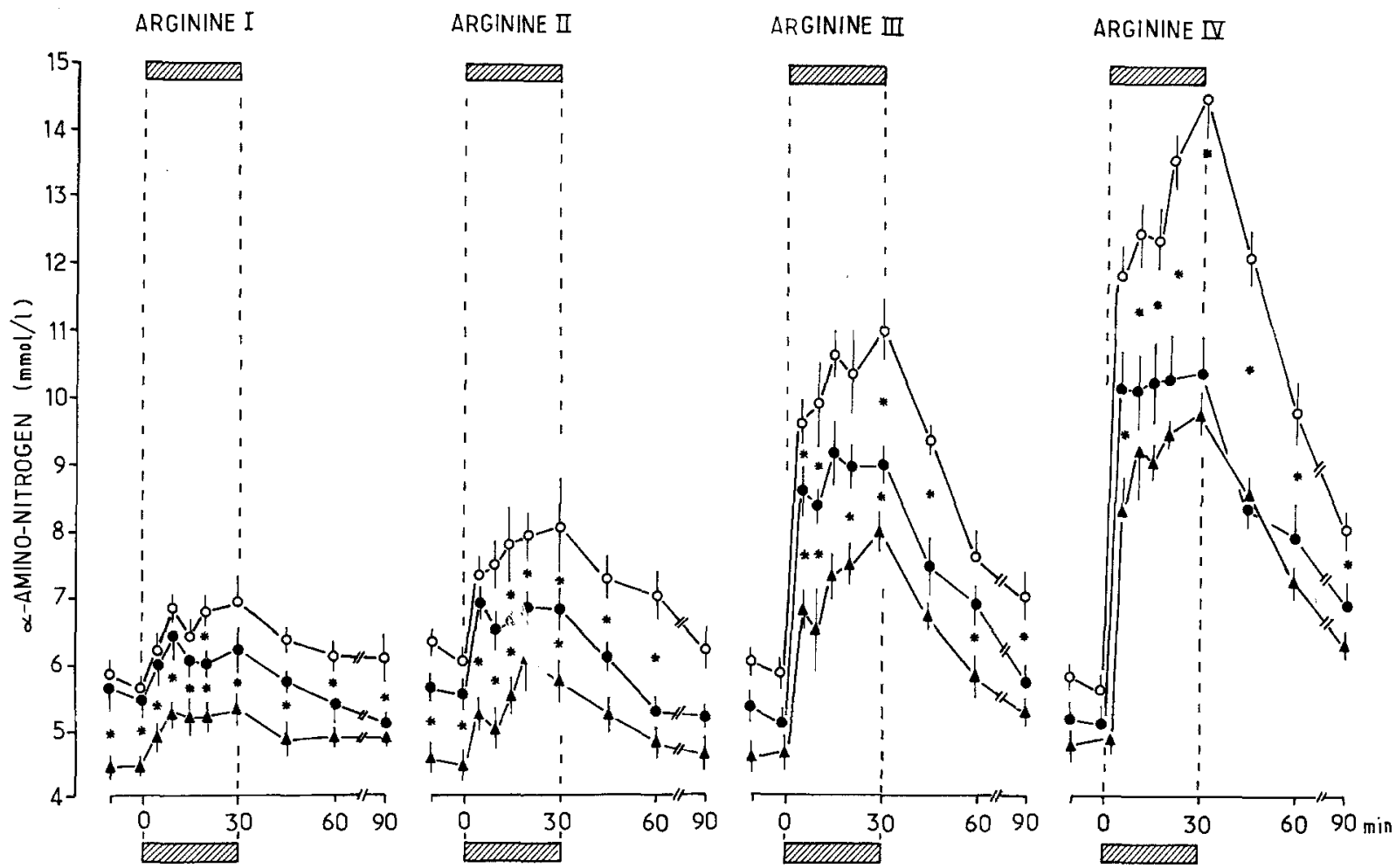

Fig. 1. Blood $\alpha$-amino-nitrogen during arginine infusions in high insulin responders $(\bullet)$, low insulin responders $(O)$ and poorly controlled diabetics ( $\mathbf{\Lambda}$ ); asterisks indicate $p<0.05$ or lower from the corresponding value in high responders. The hatched bars indicate the duration of arginine infusion. (see text for the four arginine doses)

Table 2. Blood glucose: basal values and increases over basal during arginine and arginine + glucose infusions in control and diabetic subjects

\begin{tabular}{|c|c|c|c|c|c|c|c|c|}
\hline \multirow[t]{2}{*}{ Groups } & \multirow{2}{*}{$\begin{array}{l}\text { Basal values } \\
(\mathrm{mmol} / \mathrm{l})\end{array}$} & \multicolumn{7}{|c|}{ Sum of increases over basal $\left(\mathrm{mmol} / 1^{-1} \cdot 90 \mathrm{~min}^{-1}\right)$} \\
\hline & & Arginine I & Arginine II & Arginine III & Arginine IV & $\begin{array}{l}\text { Arginine III } \\
+ \text { glucose I }\end{array}$ & $\begin{array}{l}\text { Arginine III } \\
+ \text { glucose II }\end{array}$ & $\begin{array}{l}\text { Arginine III } \\
+ \text { glucose III }\end{array}$ \\
\hline \multicolumn{9}{|l|}{ Control subjects } \\
\hline High responders & $4.2 \pm 0.1$ & $0.4 \pm 0.6$ & $1.6 \pm 0.4$ & $0.8 \pm 0.7$ & $1.0 \pm 0.9$ & $10.4 \pm 0.8$ & $19.5 \pm 0.5$ & $55.0 \pm 2.0$ \\
\hline Low responders & $4.3 \pm 0.1$ & $1.1 \pm 0.4$ & $2.5 \pm 0.6$ & $1.9 \pm 0.7$ & $1.9 \pm 0.4$ & $9.2 \pm 0.8$ & $38.0 \pm 1.1^{\mathrm{b}}$ & $80.0 \pm 6.5^{b}$ \\
\hline \multicolumn{9}{|l|}{ Diabetic subjects } \\
\hline Fair control & $9.3 \pm 0.3^{b}$ & $8.4 \pm 2.7^{\mathrm{a}}$ & $8.8 \pm 3.9^{\mathrm{a}}$ & $19.6 \pm 2.7^{\mathrm{b}}$ & $26.4 \pm 3.0^{\mathrm{b}}$ & - & - & $130.1 \pm 5.0^{\mathrm{b}}$ \\
\hline Good control & $4.3 \pm 0.7$ & - & & $5.5 \pm 3.6$ & - & - & - & $45.5 \pm 3.5$ \\
\hline
\end{tabular}

Increases over basal represent the algebraic sums of variations from basal values (i. e. the mean of time samples -15 and zero min) as calculated from time samples $+5,10,15,20,45,60$ and $90 \mathrm{~min}$. Results are presented as mean \pm SEM. Statistical significance of differences with high insulin responders ${ }^{a} p<0.01 ;{ }^{b} p<0.001$

\section{Arginine Infusion Tests}

In general, during the arginine loadings higher blood $\alpha-\mathrm{NH}_{2}$ values were observed in the low-insulin responders and lower values in the diabetics when compared with the high insulin responders (Fig. 1). The magnitude of the increase was similar in all groups for any given increase in the dose of arginine used.

In high insulin responders, blood glucose displayed the usual slight rise followed by a minor decrease.
The rise was more pronounced in low responders and even more so in the diabetics (Table 2).

Plasma IRG rose proportionally to the arginine dose in all groups, even with the lowest infusion rate (Fig. 2). With the two lowest arginine doses, peak values were reached at $5 \mathrm{~min}$, with arginine III and IV at $30 \mathrm{~min}$. Plasma IRG returned to baseline at $90 \mathrm{~min}$ or earlier, except in the case of arginine IV. In the diabetic patients plasma IRG was always higher than in non-diabetic subjects. The differences between dia- 

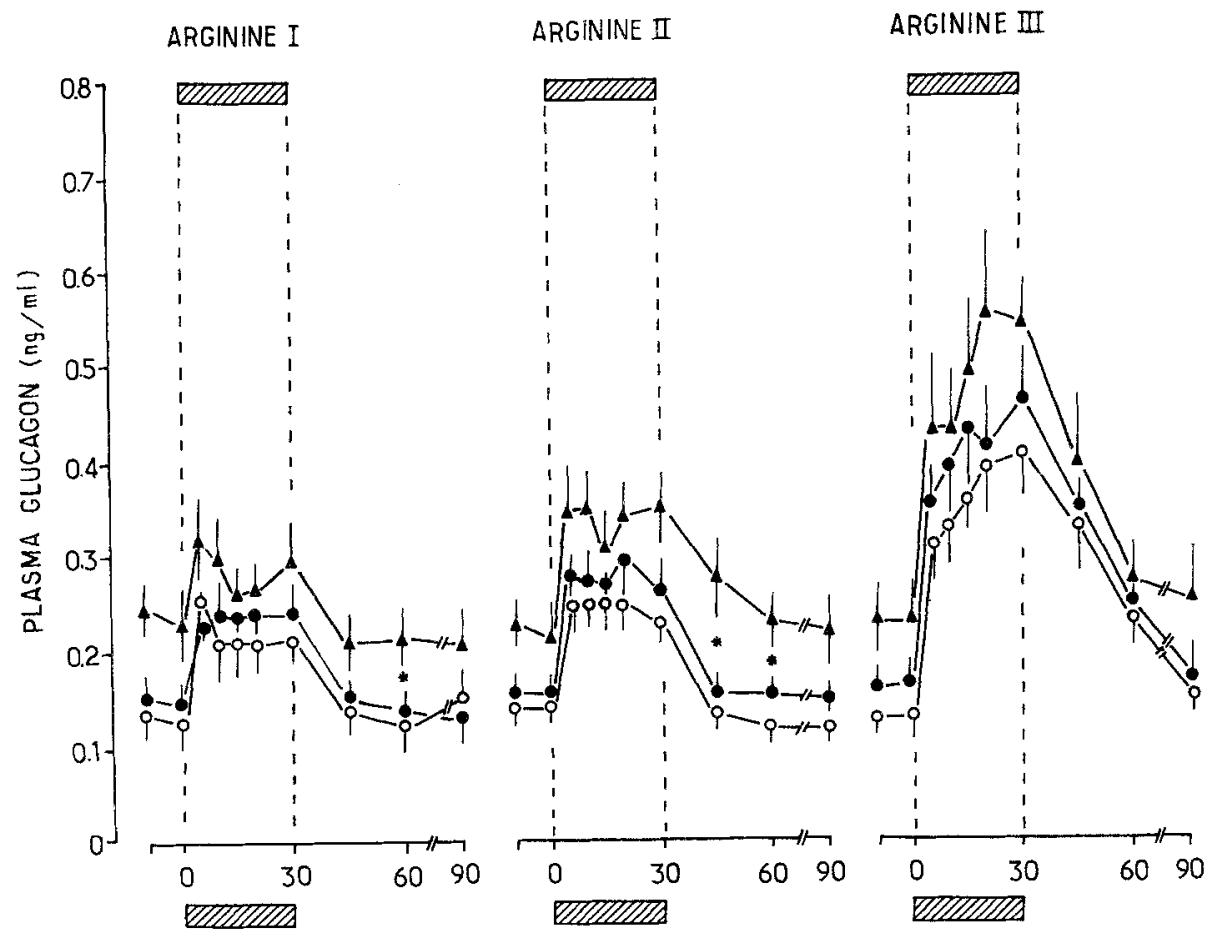

ARGININE IV

Fig. 2. Plasma glucagon variations during arginine infusions in high insulin responders ( $\bullet$ ), low insulin responders (O) and poorly controlled diabetics ( $\mathbf{\Lambda}$ ). Results are presented as in Fig. 1

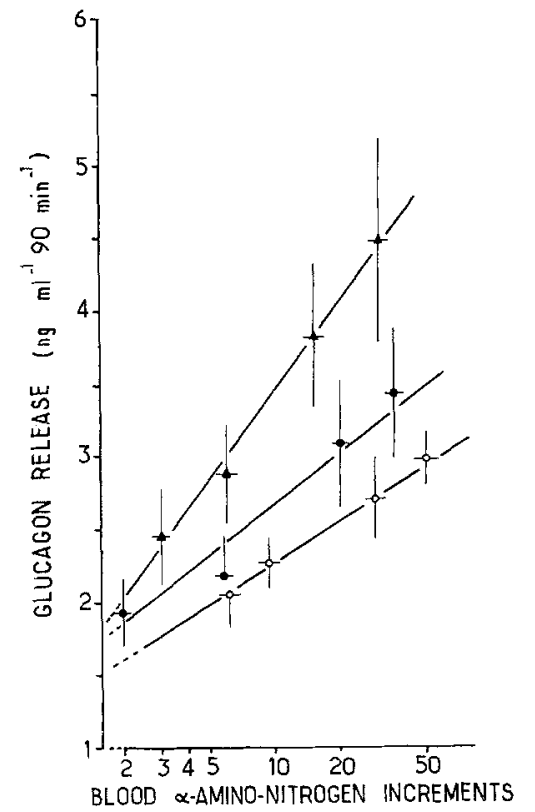

3

( $\left.m \mathrm{~mol}^{-1} 90 \mathrm{~min}^{-1}\right)$

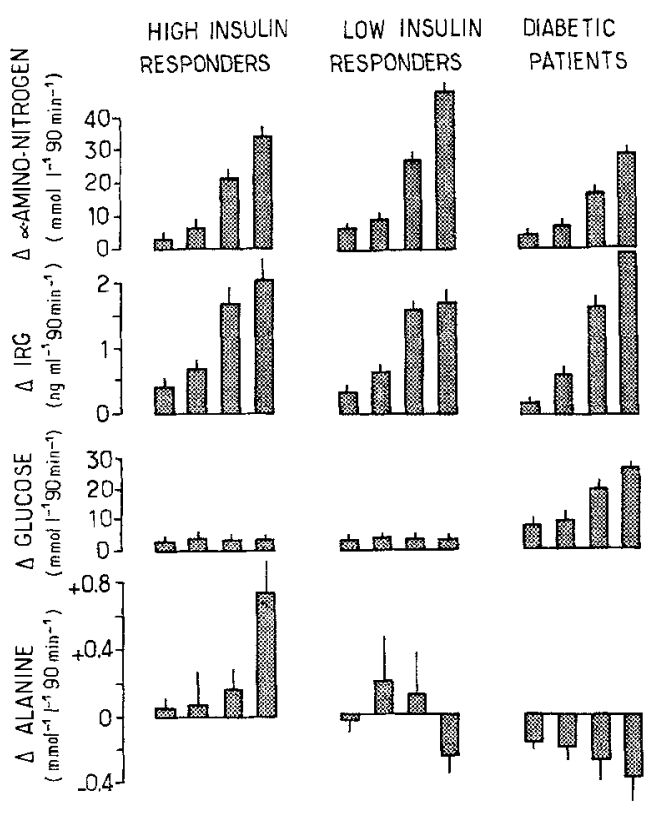

4

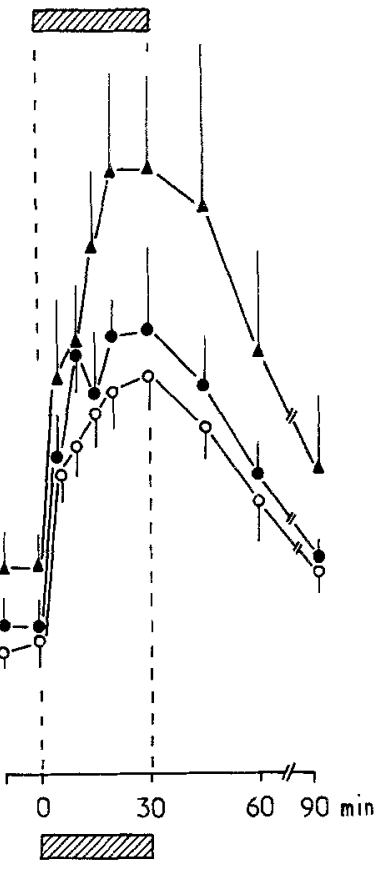
the glucagon responses (sum of glucagon values for $90 \mathrm{~min}$ ) to the corresponding $\alpha$-amino-nitrogen increases in high insulin responders $(-)$, low insulin responders $(O)$ and diabetics $(\mathbf{\Delta})$. Results are presented as mean $\pm \mathrm{SEM}$. Equations for dose response curves were: $y=1.29 \log x$ +1.34 in high insulin responders $(n$ $=14) ; y=1.20 \log x+1.03$ in low insulin responders $(n=10) ; y=2.08$ $\log x+1.30$ in diabetics $(n=10)$

Fig. 4. Algebraic sum of variations from basal values of $\alpha$-amino-nitrogen, glucagon (IRG), glucose and alanine during the $90 \mathrm{~min}$ of the tests. Algebraic sum of variations from basal was calculated as in Tables 1 and 2. The four columns in each group of results correspond to the four doses of arginine (see text for details on the arginine infusions)

were, in most instances, lower in the low responders than in high responders.

There was a linear relationship between the integrated IRG response over $90 \mathrm{~min}$ and the $\log$ of $\alpha-\mathrm{NH}_{2}$ increase $(r=0.98$ to $0.99 ; p<0.05$, Fig. 3$)$. The slope was steeper in diabetics than in non-diabetic

betics and high insulin responders were significant at a few time-points. On the other hand, comparisons between diabetics and low insulin responders yielded significant differences at almost all sampling times. No significant differences were observed between high and low responders, but IRG response curves 
Table 3. Plasma insulin: basal values and increases over basal during arginine and arginine + glucose infusions in the control subjects with high and low insulin responses

\begin{tabular}{lllllllll}
\hline Groups & $\begin{array}{l}\text { Basal values } \\
(\mathrm{mU} / \mathrm{l})\end{array}$ & \multicolumn{2}{l}{ Sum of increases over basal $\left(\mu \mathrm{U} \cdot \mathrm{ml}^{-1} \cdot 90 \mathrm{~min}^{-1}\right)$} \\
\cline { 3 - 8 } & & Arginine I & Arginine II & Arginine III & Arginine IV & $\begin{array}{c}\text { Arginine III } \\
+ \text { glucose I }\end{array}$ & $\begin{array}{c}\text { Arginine III } \\
+ \text { glucose II }\end{array}$ & $\begin{array}{c}\text { Arginine III } \\
+ \text { glucose III }\end{array}$ \\
\hline High responders & $24 \pm 1$ & $53 \pm 12$ & $102 \pm 13$ & $236 \pm 30$ & $255 \pm 29$ & $392 \pm 54$ & $540 \pm 95$ & $1062 \pm 118$ \\
Low responders & $24 \pm 1$ & $52 \pm 24$ & $70 \pm 12$ & $106 \pm 29^{\mathrm{a}}$ & $125 \pm 29^{\mathrm{a}}$ & $246 \pm 67$ & $333 \pm 50$ & $445 \pm 60^{\mathrm{a}}$ \\
\hline
\end{tabular}

Results are presented as in Table $2{ }^{\text {a }}$ Statistical significance of differences between the two groups: $p<0.001$

subjects, but was similar in high and low insulin responders.

Biphasic insulin responses were obtained for all doses of arginine both in high and low insulin responders. The increases in insulin and the $\alpha-\mathrm{NH}_{2}$ were highly correlated in both groups $(r=0.96$ and $0.97)$. The insulin response was lower in low responders than in high responders (Table 3). This difference was even more striking considering the higher blood glucose and $\alpha-\mathrm{NH}_{2}$ levels in low insulin responders to arginine in all experiments.

Arginine infusions exerted modest non-significant effects on blood alanine concentration in the non-diabetic subjects. In contrast, in the insulin deficient patients IV arginine induced a decrease in alanine concentration (Fig. 4), which was time-related (Fig. 5) and dose-related with $\alpha-\mathrm{NH}_{2}$ and IRG changes ( $r=-0.97$ and -0.98 respectively).

\section{Effects of Infusions of Glucose Together with Arginine}

As shown in Table 2, the increases in blood glucose were significantly higher in low than in high insulin responders, and considerably more so in the diabetics with fair metabolic control. In the diabetics with good control, the increases in blood glucose concentrations were similar to those of normal subjects (Table 2). The blood $\alpha-\mathrm{NH}_{2}$ elevation following arginine was not influenced by the glucose or insulin infusions.

The effect of glucose III on the glucagon response to arginine III is shown in Figure 6. A significant decrease in plasma glucagon was obtained both in high and in low insulin responders. There was a linear relationship between the degree of inhibition of glucagon secretion and the log of the corresponding increase in blood glucose following the infusion of the three doses of glucose into the high and low insulin responders (Fig. 7). The degree of A cell inhibition by glucose was similar in these two groups but no inhibitory effect of glucose could be demonstrated in the diabetics with fair control (Figs. 6 and 7). However, when these patients were intensively treated with insulin, fasting plasma glucagon returned towards normal

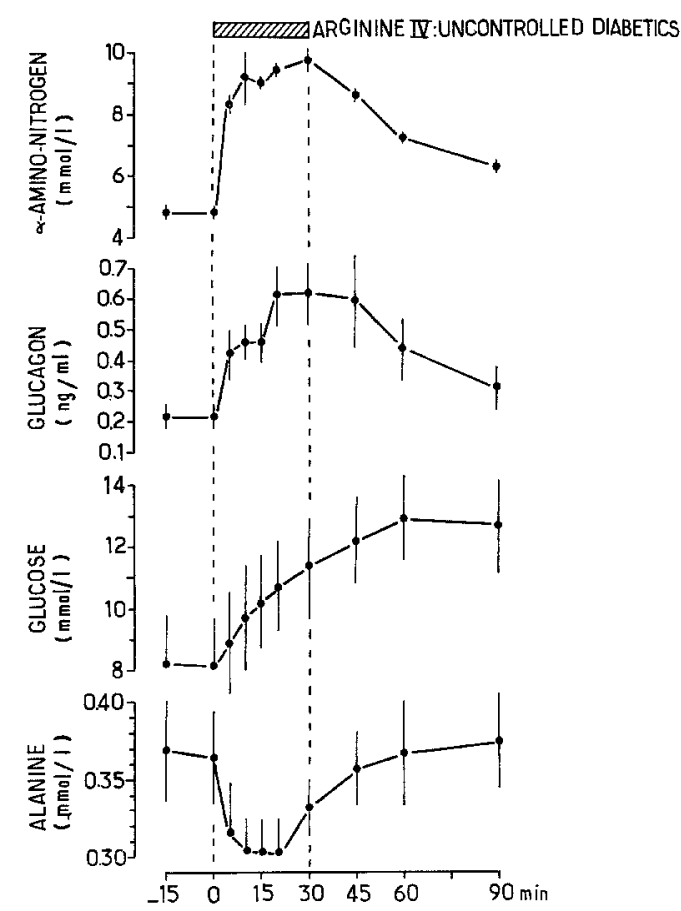

Fig. 5. Time course of $\alpha$-amino-nitrogen, glueagon, glucose and alanine during infusion of arginine IV in poorly controlled diabetics $(n=10)$. The hatched bar indicates the duration of infusion

$(176 \pm 16 \mathrm{pg} / \mathrm{ml})$ and the arginine infusion significantly suppressed the A cell response both with and without the administration of glucose (Figs. 7 and 8).

The addition of glucose to arginine significantly augmented the insulin responses in high as well as low insulin responders (Table 3 ).

\section{Effect of Insulin-Induced Hypoglycaemia}

Insulin-induced hypoglycaemia to a mean value of $1.9 \pm 0.1 \mathrm{mmol} / 1$ in five aggressively treated diabetics, resulted in a plasma IRG of $220 \pm 33 \mathrm{pg} / \mathrm{ml}$ at $30 \mathrm{~min}$. This value was similar to that obtained after an overnight fast in the 10 well-controlled patients $(176 \pm 16 \mathrm{pg} / \mathrm{ml})$. 

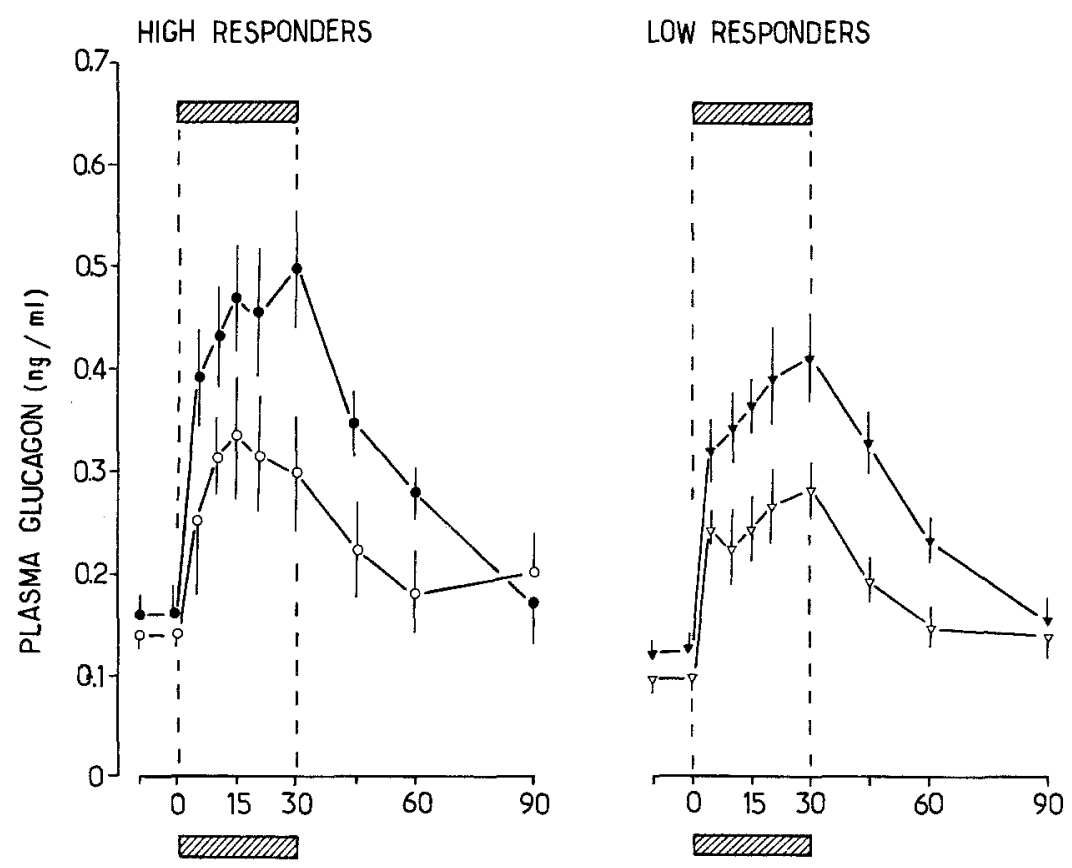

UNCONTROLLED DIABETICS

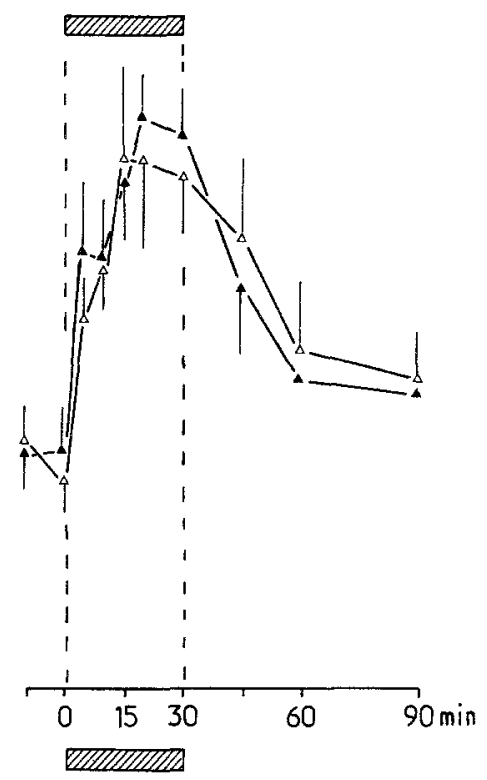

Fig. 6. Plasma glucagon response to arginine III (closed symbols) and arginine III + glucose III (open symbols) in high insulin responders $(\bullet, n=14, \mathrm{O}, n=12)$, low insulin responders $(\nabla, n=10, \nabla, n=6)$ and diabetics $(\Delta, n=10, \Delta, n=10)$ in absence of good metabolic control. Hatched bars indicate the duration of infusions

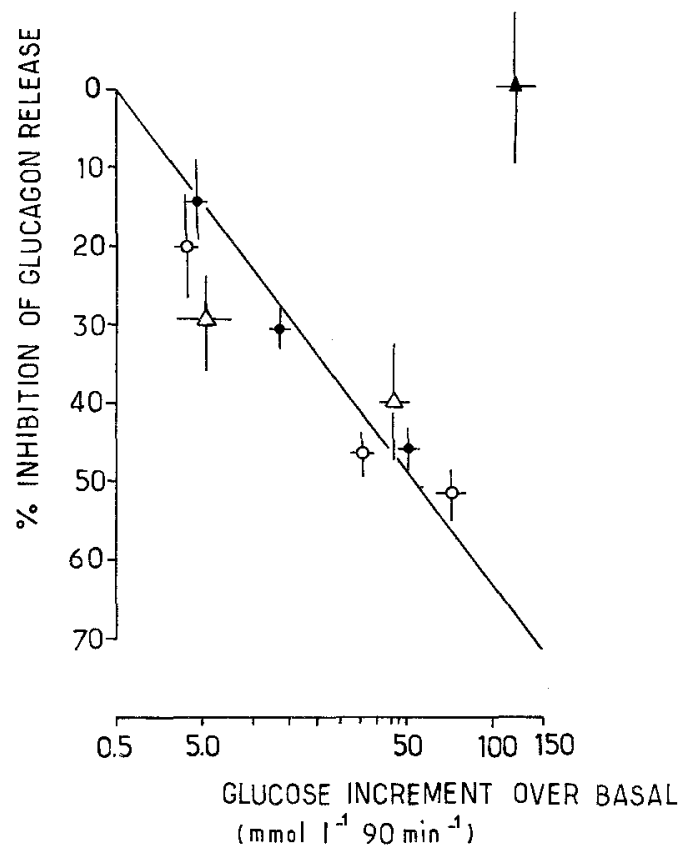

Fig. 7. Inhibition of the glucagon response to arginine III by glucose I, II and III. The glucagon response to arginine + glucose (sum of values over $90 \mathrm{~min}$ ) has been calculated as percentage of the response to arginine alone, and plotted against the concomitant incremental blood glucose levels (sum of values over $90 \mathrm{~min}$ ). High insulin responders $(\bullet, n=8)$, low insulin responders $(O, n=8)$, uncontrolled diabetics $(\Lambda, n=10)$ and tightly controlled diabetics $(\triangle, n=10)$. Results are presented as mean \pm SEM

\section{Discussion}

Many of our results confirm findings that are already well established, such as islet A cell hyperactivity during poor control of blood glucose in diabetes [16-17], increased glucagon response to amino-acids [17-20] and non-suppressibility of glucagon release by glucose in diabetics [21]. In addition our dose-response studies suggest that in diabetics it is the capacity rather than the sensitivity of the A cell response to arginine which is augmented.

It is shown here clearly that A cell dysfunction in insulin dependent diabetics is related to metabolic changes and disappears with good control of the blood glucose. Several recent studies have also demonstrated that fasting glucagon levels, the glucagon response to arginine, and its suppressibility by glucose can be restored to normal or near-normal by intensive insulin therapy [21-27]. Not only insulin dependent patients but also insulin independent diabetics demonstrate hyperactivity of A cells [28]. In these patients only very high doses of insulin could normalize the glucagon levels [28], but such subjects display a relative insulin deficiency and insulin resistance.

Supraphysiological doses of insulin are usually necessary to achieve A cell normalization in diabetic man or animals. However, this may simply mean re- 

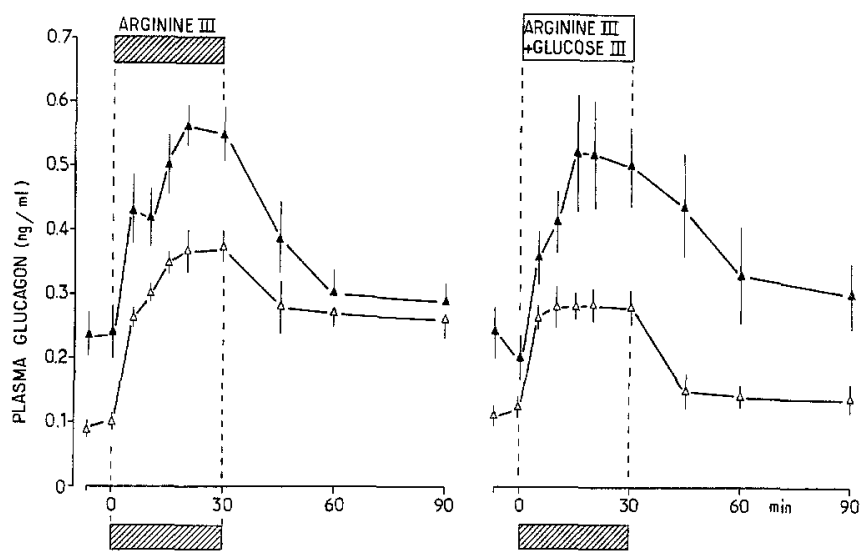

Fig. 8. Plasma glucagon responses to arginine III (left panel) and arginine III + glucose III (right panel) in diabetics in the absence $(\Lambda, n=10)$ and in the presence $(\triangle, n=10)$ of tight metabolic control. Results are presented as mean \pm SEM

constitution of the high insulin concentrations which are supposed to exist at the vicinity of A cells [29]. When minute amounts of insulin were continuously infused into diabetics by a glucose controlled device or an open loop system $[8,27]$ several days or weeks were necessary to normalize the plasma glucagon level. This inability of an acute insulin infusion to correct A cell reaction to amino acids and glucose in diabetic patients [22-24] is not necessarily in conflict with our results since complete normalization of the metabolic state can hardly be achieved under short-term conditions.

Insulin reduces the A cell response in vitro to amino acids by the pancreas of alloxan-diabetic rats [32] and to a lesser extent by the pancreas from streptozotocin-diabetic rats [33]. This insulin sensitivity of diabetic A cells, albeit incomplete in some cases, is consistent with the suppressibility of normal A cells by glucose only in the presence of insulin.

Our observations in low insulin responders do not support the concept of a primary A cell abnormality in insulin independent diabetes. A markedly higher probability to develop diabetes has been established by the follow-up of these subjects over a 1-10 year period [10], which strongly suggests that this condition is somehow related to insulin independent diabetes. The low insulin responders displayed normal fasting glucagon levels and a normal A cell suppression of glucose. Their A cell responses to arginine were, if anything, slightly lower than normal, possibly because of the slightly higher blood glucose values following arginine infusion. Our findings are in agreement with other results in the literature. Thus, normal A cell response to arginine and to glucose was observed in non-diabetic Pima Indians with both par- ents diabetic [30, 31, 34], in the mothers of big neonates with gestational diabetes [35] and in a monozygotic triplet with two diabetic brothers, who was studied for 2 years before the appearance of diabetes [36]. These results are at variance with two other studies on the discordant monozygotic twins of diabetics [37] and first degree relatives of diabetics [38] where the insulin response to glucose was slightly impaired and the glucagon was not suppressed.

The finding of somewhat lower fasting and postarginine glucagon levels in our low insulin responders is of interest. It was demonstrated [39] that these subjects have a lower than normal splanchnic glucose production rate, probably thus partially compensating for their insulin deficiency. Whether these two observations are causally interrelated cannot be decided from the present study.

Once diabetes is established glucagon oversecretion may play an important role in aggravating the characteristic metabolic disturbances [40-48] but our results support the idea that A cell dysfunction is not a primary cause of the disease.

\section{References}

1. Unger RH (1976) Diabetes and the alpha cell. Diabetes 25: $136-151$

2. Gerich JE, Lorenzi M, Karam JH, Schneider V, Forsham PH (1975) Abnormal pancreatic glucagon secretion and postprandial hyperglycaemia in diabetes mellitus. J Am Med Assoc 234: $159-165$

3. Felig R, Wahren T, Sherwin R, Hendler R (1976) Insulin, glucagon and somatostatin in normal physiology and diabetes mellitus. Diabetes 25: 1901-1099

4. Gerich JE, Langlois M, Noacco C, Karam JH, Forsham PH (1973) Lack of glucagon response to hypoglycaemia in diabetes: evidence for an intrinsic pancreatic alpha-cell defect. Science 182: 171-173

5. Gerich JE, Tsalikian E, Lorenzi M, Karam JH, Schneider V, Gustafson G, Bohannon NV (1975) Normalization of fasting hyperglucagonaemia and excessive glucagon responses to I. V. arginine in human diabetes mellitus by prolonged perfusion of insulin. J Clin Endocrinol Metab 41: 1178-1180

6. Raskin P, Unger RH (1978) Effects of insulin therapy on the profile of plasma immunoreactive glucagon in juvenile type and adult-type diabetics. Diabetes $27: 411-419$

7. Raskin P, Unger RH (1978) Hyperglucagonaemia and its suppression. N Engl J Med 299: 433-436

8. Raskin R, Pietri A, Unger RH (1979) Changes in glucagon levels after 4 to 5 weeks of glucoregulation by portable insulin infusion pumps. Diabetes 28: 1033-1035

9. Cerasi E, Luft $R$ (1967) The plasma insulin response to glucose infusion in healthy subjects and in diabetes mellitus. Acta Endocrinol 55:278-304

10. Cerasi E, Luft R (1967) Follow-up of non-diabetic subjects with normal and decreased insulin response to glucose infusion. First report. Horm Metab Res (Suppl 5): 111-120

11. Hugget ASG, Nixon DA (1957) Use of glucose oxidase, peroxidase, and $\mathrm{O}$-dianisidine in determination of blood and urinary glucose. Lancet 2: $368-370$ 
12. Malangeau P, Bourdon R, Nicaise AM, Masson B (1963) Dosage des acides aminés dans les liquides de l'organisme. Ann Biol Clin $21: 3-9$

13. Williamson DH (1970) Alanine. In: Bergmeyer HU (ed) Methoden der enzymatischen Analyse. Verlag Chemie, Weinheim 1364-1373

14. Assan R, Tchobroutsky G, Derot M (1971) Glucagon radioimmunoassay, technical problems and recent data. Horm Metab Res (Suppl 3): 82-90

15. Snedecor GW (1956) Statistical methods, 5th ed. Towa State College Press

16. Assan R, Hautecouverture M, Guillemant S, Dauchy F, Protin $\mathrm{P}$, Derot $\mathrm{M}$ (1969) Evolution de paramètres hormonaux (glucagon, cortisol, hormone somatotrope) et énergétiques (glucose, acides gras libres, glycérol) dans 10 acidocétoses diabétiques graves traitées. Pathol Biol 17: 1095-1105

17. Assan R, Rosselin G, Drouet J, Dolais J, Tchobroutsky G (1966) Taux plasmatique du glucagon chez les diabétiques. Ann Endocrinol (Paris) 27: 6-12

18. Unger RH, Aguilar-Parada E, Müller WA, Eisentraut AM (1970) Studies of pancreatic alpha cell function in normal and diabetic subjects. J Clin Invest 49: 837-848

19. Müller WA, Faloona GR, Aguilar-Parada E, Unger RH (1970) Abnormal alpha cell function in diabetes: responses to carbohydrate and protein ingestion. N Engl J Med 283: 109-1 15

20. Gerich JE, Langlois M, Noacco C, Lorenzi M, Karam JH, Forsham PH (1976) Comparison of the suppressive effects of elevated plasma glucose and free fatty acid levels on. glucagon secretion in normal and insulin-dependent diabetic subjects. $J$ Clin Invest $58: 320-325$

21. Ohneda A, Ishii S, Horigome K, Yamagata S (1975) Glucagon response to arginine after treatment of diabetes mellitus. Diabetes 24:811-819

22. Unger RH, Madison LL, Müller WA (1972) Abnormal cell function in diabetes. Response to insulin. Diabetes 21:301-307

23. Braaten JT, Faloona GR, Unger RH (1974) The effect of insulin on the alpha-cell response to hyperglycaemia in long-standing alloxan diabetes. J Clin Invest 53: 1017-1021

24. Raskin P, Aydin I, Unger RH (1976) Effect of insulin on the exaggerated glucagon response to arginine stimulation in diabetes mellitus. Diabetes 25:227-229

25. Raskin P, Fujita Y, Unger RH.(1975) Effect of insulin-glucose infusions on plasma glucagon levels in fasting diabetics and non-diabetics. J Clin Invest 56: 1132-1138

26. Gerich JE, Lorenzi M, Tsalikian E, Bohannon NV, Schneider V, Karam JH, Forsham PH (1976) Effects of acute insulin withdrawal and administration on plasma glucagon responses to intravenous arginine in insulin-dependent diabetic subjects. Diabetes 25:955-960

27. Kerner W, Pfeiffer EF (1977) Glucagon secretion in diabetics during glucose-controlled insulin infusion. Diabetologia 13: 408

28. Unger RH, Madison LL, Müller WA (1972) Abnormal alphacell function in diabetics: response to insulin. Diabetes 21: 301-307

29. Unger RH, Raskin P, Srikant CG, Orci L (1977) Glucagon and the A-cell. Rec Prog Horm Res 33: 477

30. Aronoff SL, Bennett PH, Rushforth NB, Miller M, Unger RH (1976) Arginine-stimulated hyperglucagonaemia in diabetic Pima Indians. Diabetes 25:404-407

31. Aronoff SL, Bennett PH, Unger RH (1977) Immunoreactive glucagon (IRG) response to intravenous glucose in pre-diabetes among Pima Indians and normal Caucasians. J Clin Endocrinol Metab 44: 968-972

32. Pagliara AS, Stillings SN, Haymond MW, Hover BA, Mat- schinsky FM (1975) Insulin and glucose as modulators of the amino-acid-induced glucagon release in the isolated pancreas of alloxan and streptozotocin diabetic rats. J Clin Invest 55 : 244-255

33. Weir GC, Knowlton SD, Atkins RF, Mac Kennan KX, Martin DB (1976) Glucagon secretion from the perfused pancreas of streptozotocin-treated rats. Diabetes 25:275-282

34. Bennett PH, Aronoff SL, Unger RH (1976) Evidence for an insulin-independent alpha-cell abnormality in human diabetes. Metabolism 25: 1527-1529

35. Turner RC, Harris E, Bloom SR, Wren C (1977) Relationship of fasting plasma glucose concentration to plasma insulin and glucagon concentrations. Studies in latent diabetics and women who have produced large-for-date babies. Diabetes 26 : $166-171$

36. Ganda OP, Soeldner JS, Gleason RE, Smith TM, Kilo C, Willanson JR (1977) Monozygotic triplets with discordance for diabetes mellitus and diabetic microangiopathy. Diabetes 26 : $469-479$

37. Day JL, Tattersall RB (1975) Glucagon secretion in unaffected monozygotic twins of juvenile diabetics. Metabolism 24: 145-151

38. Kirk RD, Dunn PJ, Reaven DW, Donald RA (1975) Abnormal pancreatic alpha-cell function in first-degree relatives of known diabetics. J Clin Endocrinol Metab 40:913-916

39. Cerasi E, Wahren J, Luft R, Felig P, Hendler R(1973) The regulation of splanchnic glucose production in subjects with low in sulin response. A compensatory mechanism in prediabetes? Eur J Clin Invest 3: 193-200

40. Cherrington A, Vranic M (1974) Effect of interaction between insulin and glucagon on glucose turnover and FFA concentration in normal and depancreatized dogs. Metabolism 23: $729-744$

41. Sherwin R, Wahren J, Felig P (1976) Evanescent effects of hypo and hyperglucagonaemia on blood glucose homeostasis. Metabolism 25: 1381-1383

42. Bomboy JD, Lewis SB, Lacy WW, Sinclair-Smith BC, Liljenquist JE (1977) Transient stimulatory effect of sustained hyperglucagonaemia on splanchnic glucose production in normal and diabetic man. Diabetes 26: 1777-1784

43. Raskin P, Unger RH (1977) Effects of exogenous hyperglucagonaemia in insulin-treated diabetics. Diabetes 26: 1034-1039

44. Barnes AJ, Bloom SR, Mashiter K, Alberti KGMM, Smythe P, Turnell D (1977) Persistent metabolic abnormalities in diabetes in the absence of glucagon. Diabetologia 13:71-75

45. Dobbs R, Sakurai H, Sazaki H, Faloona G, Valverde I, Baetens D, Orci L, Unger RH (1975) Glucagon: role in the hyperglycaemia of diabetes mellitus. Science 187: 544-547

46. Mc Garry JD, Foster DW (1977) Hormonal control of ketogenesis. Arch Intern Med 137: 495-501

47. Rizza RA, Gerich JE (1979) Persistent effect of sustained hyperglucagonaemia on glucose production in man. J Clin Endocrinol Metab 48: 352-355

48. Rizza R, Verdonk C, Miles J, Service FJ, Gerich JE (1979) Effect of intermittent endogenous hyperglucogonaemia on glucose homeostasis in normal and diabetic man. J Clin Invest 63: $1119-1123$

Received: 28 January 1980

and in revised form: 17 July 1981

Dr. R. Assan

Diabetes Department

Bichat Hospital

F-75018 Paris, France 